\title{
ANALYZING THE FACTORS INFLUENCING HEALTH BEHAVIOR IN CHILDHOOD - THE IMPACT OF MEDIA- AND COMPUTER USAGE ON HEALTH BEHAVIOR ${ }^{5}$
}

\author{
Authors: \\ Tamás Józsa \\ University of Debrecen \\ Beáta Erika Nagy \\ University of Debrecen
}

E-mail address of the first author: tamasjozsa@med.unideb.hu

\section{Lectors:}

Éva Szabó

Kenézy Gyula Kórház és Rendelőintézet

Veronika Schéder

University of Debrecen

Ferenc Mező

Eszterházy Károly University

Edina Szabó

University of Debrecen

Józsa, Tamás and Nagy, Beáta Erika (2017): Analyzing the factors influencing health behavior in childhood - the impact of media- and computer usage on health behavior. Különleges Bánásmód, III. évf. 2017/1. szám, 61-67. DOI 10.18458/KB.2017.1.61

\begin{abstract}
According to WHO a new integrative mindset became relevant nowadays which sees people as bio-psycho-social-spiritual wholes. These factors start to form in childhood and those who work with people have a great responsibility to help deploying them. The media and the internet have a main role of influencing these 4 dimensions. In our article we attempt to reveal the effects of this psychologically relevant question on health behavior. Several risk behaviors can be mentioned which are caused by uncontrolled media and internet usage. Bullying through electronic devices („cyberbullying”) occurs more and more frequently which has multiple reasons. Nevertheless in connection with the social dimension of well-being an important cause of internet usage appears: the sense of belonging. The formation of health psychology was legitimate as the biomedical model failed and the expenses of health care and the interest towards the quality of life increased, also alternative solutions became more in demand.
\end{abstract}

Keywords: bio-psycho-social-spiritual integrative aspect, health behavior, media- and computer usage, health psychology

Disciplines: psychology, health psychology, communication and media studies

\footnotetext{
${ }^{5}$ The editorial board does not take any responsibilty for the English of the papers. Indeed, we made some slight changes but wanted to keep the style of the authors.
} 


\section{Absztrakt}

Napjainkban az ember bio-pszicho-szocio-spirituális modellben képzelendő el. Ez a WHO által közzétett állásfoglalás aláhúzza, hogy mindezen 4 dimenzió formálódása már gyermekkorban megkezdődik, és kialakulásukban nagy szerepe van a segítő szakmákban dolgozóknak. Ebben a cikkben azt hangsúlyozzuk, hogy az internet és a média milyen kulcsfontosságú szerepet tölt be az egészségmagatartás formálódásában. A különféle médiumok kontrollálatlan fogyasztása, a közösségi média rohamos terjedése (aminek oka a valahová tartozás érzésének elsődlegessége), valamint a cyberbullying jelensége egyaránt lépések megtételére sarkallja a pszichológusokat. Mindennek - és a biomedikális modell kudarcának - köszönhetően megszületett egy új szubdiszciplína, amelynek küldetése nem más, mint az életminőséggel történő fokozott foglalkozás, valamint a napjaink életszemléletéhez igazodó alternatív megoldások keresése.

Kulcsszavak: bio-pszicho-szocio-spirituális emberkép, egészségmagatartás, média- és számítógép-használat, egészségpszichológia

Diszciplína: pszichológia, egészségpszichológia, kommunikáció és médiatudomány

\section{THE RELEVANCE OF HEALTH BEHAVIOR AS A DISCIPLINE OF SCIENCE}

The term health psychology includes all aspects of psychology connected to health, illness, health protection and politics (Kulcsár, 2002). Studies with a positive psychology approach have a relevant role among the topics of current researches which decisively influenced the approach of health psychology. The formation of health psychology was legitimate as the biomedical model failed and the expenses of health care and the interest towards the quality of life increased, also alternative solutions became more in demand. An important goal of health psychology is prevention and education which was also our approach for this study. There's a need to identify the so called behavior pathogens which negatively influence people's health behavior as they are risk factors. Moreover it' recommended to consider not only people's environment where they lived and worked, which had a correlation to their illness but also the surroundings of the treatment. The health and illness patterns have a significant impact on one's representation (their cognitive construct, their interpretation of their health and illness). Basically two kinds of approach have to be mentioned: according to the negative definition the lack of illness is health, but the positive approach declares that something more, something extra is needed for complete health. All these are beliefs and expectations which influence healing without a doubt although doctors who treat physical symptoms can't consider these due to lack of time, resources and expertise (Diefenbach et. al., 2008). The compliance, adherence and the communication with the doctor and the medical staff are all vital aspects in connection with cooperation and decision making. In childhood the parent's attitude towards the illness is also relevant as the adults who could change their lifestyles after a serious illness did correctly detect their own roles in the formation of the illness (i.e. obesity leads to cardiological disorders). This appropriate detection of the causes led to a more efficient loss of their bad habits, more efficient than those who "only" had the doctor's advice to get rid of their bad habits (Michie, Miles \& Weinman, 2003).

Health psychology needs to examine which secondary psychological disorders can join or influence physical diseases. Education and support is vital for those who suffer from chronic diseases and for their family (Csabai \& Molnár, 2009). Health orientation is a key concept although in connection with it Freud's foundations and theories need to be reconsidered. Freud's negative view of human nature is not actual anymore as the post material values have a better impact on health than the possessions of the consumer society (Pikó, 2004). These 
values can be the feeling of belonging somewhere, the possibility of self-realization or finding that life has a meaning (Zonda \& Paksi, 2006). All these suggest an integrative concept in which people exist in a bio-psycho-social-spiritual whole - as the WHO also declares. These dimensions can facilitate the emergence and maintenance of the correct health behavior individually. The formation of these starts at childhood, also teachers, psychologists and people with other social carriers have a great role in its developing. Media and internet have an even bigger influence on it though. These are capable of concentrating all 4 aspects, the physical-psychical-social-spiritual dimensions and taking effect on children often unnoticed by the parents, several times a day.

\section{THE HUMAN HEALTH BEHAVIOR AND ITS INFLUENCING ASPECTS}

Any behavior which helps maintaining health or prevents illness according to the person is considered to be health behavior. In its developing important times are early childhood and adolescence (the critical sense is absent or opened). The internalizing of patterns happens from the family, institutions and the media. We have to mention that conscious health behavior increases in adulthood and with aging (Kulcsár, 2002). Gender differences can be detected regarding health behavior. Men are more likely to be passive during treatment (,the doctor knows better") also the staff sees that men's feedback and general attitude is more positive. Women however are more interested in the details of their illness, they're usually well informed and also it's easier for them to share their feelings. Some disorders which could be partly avoidable with education and providing information (in one word: prevention) can emerge due to a low social-economical status. Those who have a low level of SES can be described with worse health habits (i.e. smoking and alcohol), less information regarding alternative stress management techniques, different cognition of diseases, endangering behavior during pregnancies, etc. (Kulcsár, 2002). All these attitudes of parents influence the children too, who can carry these patterns. In connection with this and gender differences we mentioned before there's the fact that women usually go to doctors sooner if they have somatic reactions to stress which is caused by the society accepts women's sensitivity more. This is relevant to us as little girls had more emotional support when they showed signs of physical or emotional weakness so women have a chance to have a health behavior that includes social support. On the other hand boys are less likely to have social support, they won't care about prevention and will be most likely to belittle the first signs of illness (Csabai \& Molnár, 2009).

Back to media: it can be interesting to analyze the aspects we discussed above and the role of media more closely, as its effect grown so much that a commercial, a billboard or a TV show can have a significant impact on a child's health and illness pattern or health behavior.

\section{THE IMPACT OF MEDIA AND INTERNET USAGE ON PHYSICAL HEALTH INDEX}

Spending several hours in front of the screen takes time away from exercising which would be essential for maintaining health and the body. The fixed posture of using electrionical devices (sitting in a same position for a long time) can have a negative effect on the spine and the back. The lack of sport is an effective predictor of early death (Kopp \& Skrabski, 2009). Young people who don't do sports are less satisfied with their lives, they have lower self esteem and they experience more symptoms of depression (Pluhár, Keresztes \& Pikó, 2004). Moreover neglecting the physical dimension may lead to secondary psychic disorders (Pikó \& Keresztes, 2007). The term 'couch potato' refers to the fact youngsters have an inactive lifestyle due to constant internet usage and watching too much TV (Tapscott, 2001). 
Therefore it's vital to highlight the undeniable benefits of regular exercise in childhood. Media's role can be providing easily accessible information or inspiration in connection with popular sport events and outstanding achievements (O'Keeffe \& Clarke-Pearson, 2011).

We have to point out that in childhood sport is not mentioned as a significant aspect on its own. From a preventive point of view there are four groups of advices regarding how to avoid illness. The first group mentions the environment/weather (e.g. not to go outside when it's cold), the second talks about diet (e.g. not to eat bad quality food), the third group is about avoiding infection (e.g. the importance of washing hands) and the fourth one implies a general healthy lifestyle. This last one becomes more important with aging, there's a tendency of ignoring the actual rules and turning towards more abstract behaviors (Hansdottir \& Malcarne, 1998).For adults making efforts to enjoy the health protecting effects of sport can be a reasonable goal. Sport can also be corrective and may have vital role in healing after a disease. Physiotherapy and physical rehabilitation are necessary after an illness in order to heal, recover and get reintegrated into society as fast as possible. Even in cases where the attitude towards one's own body needs to be reevaluated exercise is still important (e.g. after losing a limb there's the possibility of para sports). After a crisis team sports can help rebuilding social dimensions: it provides space to socialize, increases self acceptance, and calls forth adequate psychical reactions (Csabai \& Molnár, 2009).

\section{THE IMPACT OF MEDIA AND INTERNET USAGE ON MENTAL HYGIENE}

A recent study's focus was on the parent's control of the children's media- and internet usage. It revealed that the majority of the parents don't restrict the children's internet usage in any way (personally or with the help of a software) (Mihalik, Szabó \& Kovács, 2014). This questions the quality of their attachment as the lack of control gives the kids power which they shouldn't have because of their age. Moreover the regular consummation of inappropriate contents can lead to depression, anxiety or mortal fear. The reason of this is that they are only observers, they can't process the stimuli properly without the presence of a grown up they're attached to (Tapscott, 2001). Regarding educational psychology the importance of this is based on that during free interactions between children topics like reality shows, talk shows and late night shows occur regularly which claims an appropriate reaction due to the children's mental health protection. In many cases parents use technical devices as a part of punishing-rewarding attitude, causing immunity in the children towards nonverbal communication, touching, storytelling and parent-children playtime. These justify interventions from professionals. More risk behavior could be mentioned due to uncontrolled media and internet usage, such as body image disorder (Nystrom, 2005). The body image presented to the consumer by the media is almost always perfect. It rarely happens that a disabled or handicapped celebrity or actor/actress appears on the screen which leads to influencing children's self esteem significantly. We mentioned the importance of social support in connection with sports and physical consequences of an illness. It's just as important (or it should be) that people who're not perfect can appear in the right mediums. Nick Vujicic's world tours are the perfect example: the young man with Serbian roots has no limbs yet he talks honestly about his difficulties and his place in society (how his classmates treated him, how could he fit in). He even mentions serious subjects as suicide, and his aim is to make the audience feel that they're not alone with their problems and they can live a full life even with disabilities. He's trying to inspire and not aiming to elicit sympathy or pity. From a preventive point of view it is important that watching TV or using the internet together with the parent can be interpreted as an attachment building and cohesive mechanism (Mihalik et. al., 2014). Individual but remotely controlled internet usage increases relevant mental aspects: correct self representation, self efficacy and impulse control can develop 
(Milkie, 1999). The feeling of competency is substantial in the cases of children who don't achieve as much at school as others (due to any reason: for example studying disorder or a low level of socialization). These children can be compensated due to the success they can achieve in the field of IT (Ryan \& Deci, 2000).

\section{THE IMPACT OF MEDIA AND INTERNET USAGE ON SOCIAL DIMENSIONS}

Cyberbullying, i.e. harassing someone through electronical devices or social media is more and more frequent which fact has various reasons. Some of these are the not age-appropriate content, the unsatisfying parental control, and the anonymity joined with the spread of chat sites and softwares. There are no consequences of foulmouthed description of others which lets „trolls” appear and spread on the internet (Wallace, 2006). At this point we have to consider the system in which the person exists: the social milieu from where the person acquires his/her culture (of conflicts) (Domonkos, 2014). The victim is usually passive, has low self esteem and socially marginalized in real life (Gradinger, Strohmeier \& Spiel, 2009). However the aspect of belonging somewhere is the main reason young people name in connection with internet and media usage. This feeling is a motivational factor connected to the social aspect of well-being (Wan \& Chiou, 2006). Belonging is a major factor in playing online multiplayer games: the players frequently communicate in 'real time', with the help of microphones while playing which provides an experience similar to personal presence (Zermatten et. al. 2011). This can have a positive effect if they can maintain the relationship in real life (for example online friendships based on comradeship can continue at school too). The social support can appear during play by the instant feedback: e.g. complimenting a good shot, a movement, etc. and expressing that the person is "good as a whole". This is based on the fact that accomplishment-based valuation is common among children: if you play well, you're a good person. You're good and acceptable as a person, not you're accomplishment. Due to this youngsters can get into situations where they act condemned by the society (e.g. cyberbullying expected by the others) to satisfy the decreased value of their own negative schema. It's important that social support and acceptance can have an impact on health behavior: the mortality of married couples is better than unmarried people's (Csabai \& Molnár, 2009).

\section{THE IMPACT OF MEDIA AND INTERNET USAGE ON THE SPIRITUAL DIMENSION}

Several studies indicated that people who believe life has a meaning or who think a greater force exists with protective will are more efficient in solving problems and can cooperate better (Kopp, Székely \& Skrabski, 2004). Supportive groups (such as online grief support groups) can help working through a trauma as they widen the social network (Tomcsányi \& Ittzés, 2010). Connection and consolation can provide coherence even at hard times (Idler et. al., 2003). Working through grief is a topic of health psychology: the person suffering from pathologic grief can find help by contacting a professional. At the end-stage of a chronic disease the person and the family can be prepared for the process, their ability to face the inevitable develops, this way they took the first step of their psychical health protection. Working through grief which can turn into a pathological grief process can take lots of time and requires active work from the family. What can help are the transpersonality, the feeling that life has a meaning or the method of logotherapy which originates from the theory of existentialism can also ease bearing the negative processes. The essence of the method Viktor E. Frankl created is that the person must look at his/her life in a perspective, as it was outgrowing him/her so it's easier to cope with irreversible losses, pain, difficulties and not 
only the person's health behavior but also his/her general mental state will improve and be more positive. The resilience is a factor which influences health behavior relevantly. This means people can adapt to a continuous, negative, tendency-like life event and still be mentally healthy when it's over (Davydov et. al., 2010). Corrective experiences (when a person can meet others with similar problems and can keep track of their healing) can offer potential to reach inner strength. A negative aspect of the spiritual dimension can be that a person might be the victim of „facelessness”. „Impersonation” happens more and more frequently: some can elicit personal data, pictures, etc. from the passive victim and then use their profiles and online contents (Willard, 2007). Joining a virtual sect or opening up to a person with an agenda can lead back to the problems of using the internet unsupervised and the pedagogic role and responsibilities of the parents.

\section{CONCLUSION}

The preventive aspects of health psychology are extremely important these days, such as the aspect of education. Besides the practical usage parents and educators can benefit from the theory and can bring up a generation whose health behavior will be more positive and healthier. Media and internet usage have a great role in this. Children use their devices all day and they also watch TV, listen to the radio which without parental control which can result in negative tendencies due to passive consummation and having online relationships instead of real life ones. It's vital to detect these and to emphasize the protective factors of media usage: using devices of modern technology may make life and learning easier, also it can widen the world if media is properly used. This way media can be a tool of increasing well-being or protecting our mental health. Moreover it's important to acknowledge that neglected aspects connected to childhood health behavior, health and illness patterns, behavior pathologies and other risk factors are specifically influenced and can improved by the media. The preventive approach of health psychology is not only cost-efficient and effective but also extremely useful for education and providing information which from professionals and others can both benefit. The usability of the data and theories at early ages can significantly contribute to create a better, more peaceful and health conscious world.

\section{REFERENCES}

Davydov, D. M., Stewart, R., Ritchie, K., \& Chaudieu, I. (2010). Resilience and mental health. Clinical Psychology Review, 30(5), 479-495.

Diefenback, M. A., Suzanne M. M., Porter, M., Peters E., Stefanek, M., \& Leventhal, H. (2008). Emotions and Health Behavior: A Self-Regulation Perspective. In M. Lewis, J. M. Haviland-Jones \& L. F. Barrett, Handbook of Emotions (pp. 645-60). New York: The Guilford Press

Domonkos, K. (2014). Cyberbullying: harassing with electronical devices (Cyberbullying: zaklatás elektronikus eszközök használatával). Alkalmazott Pszichológia, 1, 59-70.

Gradinger, P., Strohmeier, D., \& Spiel, C. (2009). Traditional bullying and cyberbullying. Zeitschrift für Psychologie/Journal of Psychology, 217(4), 205-213.

Hansdottir, I., \& Malcarne, V. L. (1998). Concepts of illness in Icelandic children. Journal of Pediatric Psychology, 23(3), 187-195.

Idler, E. L., Musick, M. A., Ellison, C. G., George, L. K., Krause, N., Ory, M. G., et al. (2003). Measuring Multiple Dimensions of Religion and Spirituality for Health Research. Research on Aging, 25(4), 327-365.

Kopp, M., \& Skrabski, Á. (2009). Hungarian state of mind after the Millennium (Magyar lelkiállapot az ezredforduló után). Távlatok, 86, 32-53. 
Kopp, M., Székely, A., \& Skrabski, Á. (2004). Religiousness and health in the changing society (Vallásosság és egészség az átalakuló társadalomban). Mentálhigiéné és Pszichoszomatika, 5(2), 104-125.

Kulcsár, Zs. (2002). Health psychology (Egészségpszichológia). Budapest: ELTE Eötvös Kiadó.

Michie, S., Miles, J., \& Weinman, J. (2003). Patient-centredness in chronic illness: what is it and does it matter? Patient Education and Counseling, 51(3), 197-206.

Mihalik, Á., Szabó, É., \& Kovács, P. (2014). The parental control of the children's computer and internet usage (A gyermekek számítógép- és internethasználatának szülői kontrollja). Alkalmazott Pszichológia, 1, 47-58.

Milkie, M. A. (1999). Social comparisons, reflected appraisals, and mass media: The impact of pervasive beauty images on Black and White girls' self-concepts. Social Psychology Quarterly, 190-210.

Molnár, P., \& Csabai, M. (2009). Medical psychology and clinical health psychology (Orvosi pszichológia és klinikai egészségpszichológia). Budapest: Medicina.

Nystrom, A. A., Schmitz, K. H., Perry, C. L., Lytle, L. A., \& Neumark-Sztainer, D (2005). The relationship of weight-related perception goals and behaviors with fruits and vegetable consumption in young adolescents. Preventive Medicine, 40(2), 403-408.

O'Keeffe, G. S., \& Clarke-Pearson, K. (2011). The impact of social media on children, adolescents, and families. Pediatrics, 127(4), 800-804.

Pikó, B. (2004). The mission of positive psychology in the modern society (A pozitív pszichológia missziója a modern társadalomban). Mentálhigiéné és Pszichoszomatika, 5(4), 289-299.

Pikó, B., \& Keresztes, N. (2007). Sport, psyche, health (Sport, lélek, egészség). Budapest: Akadémiai Kiadó.

Pluhár, Zs., Keresztes, N., \& Pikó, B. (2004). The connection of regular physical activity and psychosomatic symptoms regarding primary school students (A rendszeres fizikai aktivitás és a pszichoszomatikus tünetek kapcsolata általános iskolások körében). Sportorvosi Szemle, 4, 285-300.

Ryan, M. R., \& Deci, E. (2000). Self-Determination Theory and the facilitation of intrinsic motivation social development and well-being. American Psychologist, 55(1), 68-78.

Tapscott, D. (2001). Digital childhood. The rise of the internet generation (Digitális gyermekkor. Az internetgeneráció felemelkedése). Budapest: Kossuth Kiadó..

Tomcsányi, T., \& Ittzés, A. (2010). The main questions of studying spirituality and religiousness and the Scale of Spiritual Transcendence by Piedmont (A spiritualitás és vallásosság kutatásának kulcskérdései és a Piedmont-féle Spiritualitási és Vallási Érzület mérőskála). Psychiatria Hungarica, 25(2), 110-120.

Wallace, P. (2006). The psychology of the internet (Az internet pszichológiája). Budapest: Osiris.

Wan, C. S., \& Chiou, W. B. (2006). Why are adolescents addicted to online gaming? An interview study in Taiwan. CyberPsychology \& Behavior, 9(6), 762-766.

Willard, N. E. (2007). Cyber-Safe Kids, Cyber-Savvy Teens, Helping Young People Learn to Use the Internet Safely and Responsibly. San Francisco: Wiley \& Sons Inc.

Zermatten, A., Billieux, J., Thorens, G., Bondolfi, G., Zullino, D., \& Khazaal, Y. (2011). Motivations to play specifically predict excessive involvement in massively multiplayer online role-playing games: evidence from an online survey. European Addiction Research, 17(4), 185-189.

Zonda, T., \& Paksi, B. (2006). Data of the protective factor of religiousness regarding physical and mental health (Adatok a vallásosság protektív szerepéhez a testi és lelki egészségben). Mentálhigiéné és Pszichoszomatika, 7(1), 1-13. 